\title{
Dociekania
}

\section{Faszyzm jako symptom, funkcja i schemat ideologiczny}

Szymon Wróbel

TEKSTY DRUGIE 2021, NR 3, S. 143-165

DOI: 10.18318/td.2021.3.11 | ORCID: 0000-0002-2764-5648

\section{Pojęcie faszyzmu}

Pojęcie faszyzmu stało się dzisiaj więcej niż problematyczne. Często przywoływane, wcale nie zyskuje na znaczeniu. Z pewnością sam faszyzm nabrał nowej aktualności, ale czy wiemy jeszcze, czym jest lub czym mógłby być? Pojęcie faszyzmu tak często powraca w dyskursie publicznym i powraca z taką łatwością, że nie mamy pewności, czy panujemy nad jego definicją, tj.jego treścią i zakresem. Czym jest faszyzm, jeśli nie jest tylko ideologią polityczną, lecz także skłonnością serca? Czy faszyzm - wedle formuły Jonathana Littella - może być potraktowany jako "stan ciała"1, rodzaj urządzenia libidinalnego, zarządzającego naszym pragnieniem oraz naszymi reakcjami obronnymi? Czy uprawnione jest w ogóle mówienie o dyspozycjach faszystowskich i strukturze charakteru faszystowskiego? Czy przypadkiem dziwna

1 J. Littell Suche i wilgotne. Krótka wyprawa na terytorium faszysty, przeł. M. Kamińska-Maurugeon, Wydawnictwo Literackie, Kraków 2009.

\section{Szymon Wróbel}

- profesor filozofii

na Wydziale

Artes Liberales

Uniwersytetu

Warszawskiego

oraz W IFiS PAN. Jest

autorem licznych

książek i artykułów

rozsianych w różnych

czasopismach

naukowych. Ostatnio

zostały opublikowane pod jego redakcją,

przy współpracy

Krzysztofa

Skoniecznego, dwie

książki - Atheism

Revisited (2020) oraz

Living and Thinking in

the Post-Digital World

(2021). Aktualnie

jest kierownikiem

Laboratorium

Techno-Humanistyki

na Wydziale Artes

Liberales. 
łatwość, z jaką obecnie przywołujemy to pojęcie, nie czyni nas niewrażliwymi na przyszły faszyzm, gdy on nadejdzie?

Siedemdziesiąt lat od wydania Osobowości autorytarnejTheodora W. Adorna wciąż próbujemy przemyśleć faszyzm dnia codziennego, faszyzm nie poza demokracją, ale w demokracji ${ }^{2}$. Publikacja polskiego tłumaczenia Nowego prawicowego radykalizmu - wykładu-interwencji Adorna z $1967 \mathrm{roku}^{3}$, oraz ważnego tekstu z 1951 roku zatytułowanego Freudowska teoria i model propagandy faszystowskiej, zamieszczonego w tomie Przemyst kulturalny ${ }^{4}$, zmusza do ponownego przemyślenia nie tylko aktualności faszyzmu, lecz nade wszystko jego afektywnej mechaniki, zakorzenienia w duszach ludzi gotowych na faszyzm. Adorno ma pełną świadomość, że faszyzm jako taki nie jest zagadnieniem psychologicznym, dyspozycje psychiczne nie powodują faszyzmu. To raczej faszyzm definiuje obszar psychiczny mogący być wykorzystany przez siły promujące go z pozapsychologicznych powodów związanych z ekonomią.

W tym tekście będę pisał na temat faszyzmu jako symptomu, funkcji i ogólnego schematu ideologicznego. Zastanowię się nad tym, w jakich relacjach pozostają względem siebie te trzy sposoby jego pojmowania, czyli „faszyzm w ciele", faszyzm jako symptom konfliktów libidinalnych i wreszcie „faszyzm w ideologii”, będący schematem porządkującym rozumienie polityki, ekonomii i kultury. Należy jednak zacząć od pytań ściśle pojęciowych, tj. od pytania o sam symptom, samą funkcję i sam schemat ideologiczny. Należy zapytać: jaki symptom? Symptom czego? Funkcjonalność faszyzmu, ale jak rozumiana? Wreszcie faszyzm jako schemat porządkujący, rodzaj stereopatii, ale co i jak porządkujący?

Adorno przez całe życie buntował się przeciwko totalizacji dowolnego obszaru życia za sprawą pojęcia. Autor Dialektyki negatywnej nawoływał do wynalezienia „czułych pojęć”, tj. zmierzał do wniknięcia w immanentną treść rzeczy, a nie pojęciowego wznoszenia się ponad świat. Przeczuwał, że pojęcie dystansuje człowieka od natury, a zarazem utrwala panowanie nad naturą. Dlatego w myśleniu wszystkie pomosty i mediacje pojęciowe muszą jego

2 T.W. Adorno Osobowość autorytarna, przeł. M. Pańków, Wydawnictwo Naukowe PWN, Warszawa 2010.

3 T.W. Adorno Nowy prawicowy radykalizm, przeł. M. Ratajczak, posłowie Volker Weiß, Znak, Kraków 2020.

4 T.W. Adorno Freudowska teoria i model propagandy faszystowskiej, w: tegoż, Przemysłkulturalny. Wybrane eseje o kulturze masowej, przeł. M. Bucholc, red. T. Maślanka, R. Wiśniewski, Narodowe Centrum Kultury, Warszawa 2019. 
zdaniem zostać w końcu odrzucone. Ten sam Adorno jednak miał skłonność do nadużycia pracy pojęć, tj. do ich jawnej totalizacji. Tak się stało z pojęciami oświecenia i mitu w Dialektyce oświecenia ${ }^{5}$. Jej autor traci zupełnie na subtelności, gdy pisze, że „oświecenie jest totalitarne”, lub gdy kategorycznie stwierdza, że "przemysł kulturalny oświecenia to tylko masowe oszustwo", a "kultura masowa to absolutna imitacja"6.

Jednocześnie widzi w pojęciu sprzymierzeńca, wzywa nawet do odzyskania pojęć, albowiem ich zawieszenie, a tym bardziej unicestwienie daje kłamstwu lub imitacji pełną swobodę manewru. Zważywszy na ten dwuznaczny stosunek Adorna do pojęcia, chcę zapytać zarówno o pojęcie faszyzmu, jak i o stosunek tego pojęcia do jego symptomu, funkcji i treści ideologicznej. Czy potrzebujemy pojęcia faszyzmu? I jakiego pojęcia faszyzmu potrzebujemy? Czy też faszyzm wyczerpuje się w swej symptomatyce lub funkcjach - społecznych, ekonomicznych i politycznych? I czy ewentualny brak pojęcia faszyzmu nie zdradzałaby tego, że mamy tylko jego mnogie obrazy, impresje?

\section{Symptom faszyzmu}

Zacznijmy od pytania o symptom. Freud w znanym tekście zatytułowanym Zahamowanie, symptom, lęk pisze, że „symptom to oznaka lub zastępstwo niezrealizowanego zaspokojenia popędu, to sukces procesu wyparcia"7. Dodaje natychmiast, że wyparcie wychodzi zawsze od "ja", które czasem - na zlecenie "nad-ja" - nie chce uczestniczyć w pobudzonej w tym (das Es) obsadzie popędowej.To ważne przesądzenia. Freud zwraca uwagę, że wyparcie ma wartość porównywalną z ucieczką „ja”.,,Ja" odwraca obsadę od reprezentacji popędów, które należy wyprzeć, i używa jej do oderwania od rozkoszy na rzecz lęku. Jak działa ten mechanizm? W znanym przypadku małego Hansa niezrozumiały lęk przed koniem - to symptom, niezdolność wyjścia na ulicę - stanowi zahamowanie, ograniczenie, które dziecko nakłada na siebie, by nie budzić symptomu lękowego. Czy zatem faszyzm jako symptom byłby symbolem sukcesu procesu wyparcia? Czy faszyzm byłby po prostu efektem ucieczki

5 T.W. Adorno, M. Horkheimer Dialektyka oświecenia, przeł. M. Łukasiewicz, Wydawnictwo IFiS PAN, Warszawa 1994.

6 Tamże, s. 40.

7 S. Freud Zahamowanie, symptom, lęk, w: tegoż Histeria i lęk, przeł. R. Reszke, Wydawnictwo KR, Warszawa 2001, s. 203. 
ze sceny aparatu psychicznego „ja” i nastaniem epoki lęku? Nie spieszmy się może z przesądzeniami.

Autor tekstu Zahamowanie, symptom, lęk nie zadowala się przecież samym pojęciem symptomu lub lęku, stawia pytanie o losy uaktywnionej w „ono” (tym, das Es) siły popędowej. Freud pyta: jakim sposobem brak rozkoszy mógłby być rezultatem zaspokojenia popędu? Skąd pochodzi energia wykorzystywana do wytworzenia sygnału o braku rozkoszy? Brak rozkoszy to lęk. Freud zadaje także pytanie, co stanowi rdzeń symptomu. Czy w przypadku Hansa np. przewidywanie, że koń go ugryzie, znajduje proste zastępstwo w postaci fobii, w jakiej występuje lęk, a nie obiekt lęku? Freud próbuje wreszcie zrozumieć relacje między treścią formacji symptomatycznej a ukrytą siłą życzeniową. Symptom staje się formacją symptomatyczną, ta jednak okazuje się formacją zastępczą. Gdybyśmy zatem poważnie potraktowali myśl o faszyzmie jako symptomie, musielibyśmy się zastanowić, w jakim sensie faszyzm stanowi formację zastępczą. Co zastępuje? Czy demokrację? Jak faszyzm zastępuje demokrację? Co w niej podlega przemieszczeniu?

Jeśli u małego Hansa ukrytą siłą jest wrogie nastawienie wobec ojca, to dlaczego Hans nie wzbudził w sobie skłonności do złego obchodzenia się z końmi, np. bicia ich lub uśmiercania? Freud z przykrością przytomnie konkluduje - „A zatem coś tu jest nie w porządku: albo w naszym ujęciu wyparcia, albo w naszej definicji symptomu"8. Zaczyna rozumieć, że wyparcie nie jest jedynym środkiem danym „ja” do odpierania przykrej siły popędowej. Freud musi uznać, wbrew swoim wcześniejszym rozpoznaniom, że to lęk często rodzi wyparcie, a zatem istnieje przed wymogami libido. „Lęk nigdy nie rodzi się z wypartego libido" . Lęk nie jest już symptomem, lecz staje się przyczyną, a wyjaśnienie źródła lęku okazuje się kluczowe. Lęk to brak rozkoszy, w który zaangażowane są procesy motoryczne zawiadujące odprowadzaniem energii, np. narządy oddychania i pompowania krwi. Lęk jest wreszcie „oczekiwaniem na traumę”, a jednocześnie jej „złagodzonym powtórzeniem”. Gdyby ponownie nasza analogia z faszyzmem była zasadna, należałoby powiedzieć, że faszyzm jest nie tylko symptomem stłumienia demokracji, lecz często także przyczyną jej zniknięcia. Symptom w tym ujęciu staje się zarówno oznaką braku, jak i siłą coś wywołującą.

Na koniec Freud twierdzi, że istnieje wiele nerwic niewykazujących śladu lęku, np. histeria konwersyjna składa się z symptomów bez domieszki lęku.

8 Tamże, s. 215.

9 Tamże, s. 220. 
W jej wypadku mamy sytuację zespolenia zakazu z zaspokojeniem. W najsurowszym przypadku - pisze Freud - symptom pojawia się w dwuczasie. Oznacza to, że zaraz po działaniu przymusowym, natrętnym, symptomatycznym pojawia się drugie działanie, które znosi lub odwołuje to pierwsze, nawet jeśli sprawia wrażenie jego przeciwieństwa. Faszyzm w tym ujęciu byłby zatem drugim czasem demokracji. Czasem braku rozkoszy, który anuluje czas rozkoszy, tj. czas demokracji. Faszyzm odwołuje demokrację bez sprawiania wrażenia lub impresji, że jest jej przeciwieństwem.

\section{Ludzie gotowi na faszyzm}

Adorno deklaruje, że przedmiotem jego analizy nie są zdeklarowani faszyści. Zacznijmy od stwierdzenia zasadniczego, że Osobowość autorytarna nie jest książką na temat Eichmanna, będącego przedmiotem subtelnego studium moralnego zatytułowanego Eichmann w Jerozolimie. Rzecz o banalności zła Hannah Arendt. Nie jest to też analiza pornofaszysty pokroju Maximiliana Auego - bohatera powieści Jonathana Littella Easkawe, ani nawet studium o Leonie Degrelle'u, belgijskim naziście, jednym z prototypów postaci Auego - obiekcie analizy eseju Suche $i$ wilgotne tego samego autora. Co więcej, Osobowość autorytarna nie jest również studium na temat "młodocianego faszyzmu" lub dojrzewania do faszyzmu, będącego przedmiotem analizy wielkiej książki Klausa Theweleita zatytułowanej Męskie fantazje, poświęconej problemowi kształtowania się wyobrażeń i pragnień wśród zdemobilizowanych po I wojnie światowej żołnierzy Freikorpsów. O kim zatem pisze Adorno?

Pisze on o ludziach w Ameryce "gotowych na faszyzm", ale myślących o sobie w kategoriach konserwatywnych lub nawet liberalnych. Diagnozuje zatem szanse tryumfu faszyzmu w Ameryce. Powiedzmy, że tworzy filozoficzny odpowiednik Spisku przeciwko Ameryce Philipa Rotha. Osobowość autorytarna jest książką na temat narodzin faszyzmu w demokracji, a nie po demokracji lub przeciw demokracji. To zbliża dzieło Adorno do subtelnych analiz Alexisa de Tocqueville'a z Demokracji w Ameryce, choć ten ostatni nie mówił, co oczywiste, o faszyzmie, lecz o skłonnościach antydemokratycznych w samej radykalnej demokracji ${ }^{10}$. Adorno deklaruje explicite, że centralnym punktem jego zainteresowania jest „jednostka potencjalnie faszystowska”, czyli jednostka o takiej strukturze osobowości, która czyni ją szczególnie podatną na antydemokratyczną propagandę. Dodaje: „Mówimy «potencjalnie», ponieważ

10 A. de Tocqueville O demokracji w Ameryce, przeł. B. Janicka i M. Król, Aletheia, Warszawa 2005. 
nie zajmowaliśmy się osobami, które są zdeklarowanymi faszystami tudzież należały do znanych organizacji faszystowskich"11. To ważna uwaga, wręcz rozstrzygająca metodologicznie.

Ludzie gotowi na faszyzm to osoby, które byłyby gotowe zaakceptować faszyzm, gdyby ten przekształcił się w silny i możliwy do uznania ruch społeczny. Wydaje się, że sam Adorno jest zaskoczony swoim odkryciem, albowiem dyspozycja faszystowska okazuje się w dużym stopniu niezależna od pozycji lub identyfikacji klasowej. Konstatuje ze zdziwieniem, że zwykle ludzie skłonni są zaakceptować takie projekty polityczne, które pozwalają im wierzyć, że zabezpieczą ich interesy ekonomiczne. Zwykle treść tych interesów zależy od pozycji jednostki w społeczeństwie, definiowanej w kategoriach ekonomicznych. Z faszyzmem jest jednak inaczej. Motywy ekonomiczne jednostki nie odgrywają tu dominującej i rozstrzygającej roli, jaką zwykle im się przypisuje. Adorno dodaje: „Aby wyjaśnić, dlaczego ludzie o tym samym statusie socjoekonomicznym tak często bywają uwikłani w odmienne ideologie, podczas gdy ludzie o różnym statusie wikłają się często w ideologie bardzo podobne, musimy wziąć pod uwagę inne potrzeby niż czysto ekonomiczne"12. To kolejna niezwykle ważna konstatacja, sugerująca, że myślenie kategoriami klas i usytuowania klasowego nie wystarcza do zrozumienia protofaszysty lub potencjalnego faszysty. Wielkim odkryciem autora Osobowości autorytarnej jest zatem to, że ludzie nie działają w zgodzie z własnym interesem materialnym, nawet jeśli potrafią ów interes zlokalizować i zdiagnozować. To problematyzuje nasze pojęcie faszyzmu jako funkcji. Czy mamy uznać, że faszyzm jest niefunkcjonalny, nieracjonalny, regresywny lub destrukcyjny, tj. po prostu nihilistyczny?

Zanim odpowiemy na to pytanie, wróćmy raz jeszcze do pojęcia symptomu. Kiedy mówimy, że faszyzm jest symptomem, to co właściwie mówimy? Symptomem jakich konstrukcji jest faszyzm? Adorno na tym etapie swych analiz twierdzi, że charakterystyczna dla osobowości autorytarnej nieświadoma wrogość, wynikająca z frustracji i represji, zostaje oderwana od swoich właściwych przedmiotów, co rodzi potrzebę obiektu zastępczego. W tym znaczeniu antysemityzm staje się funkcjonalny. I w mniejszym stopniu zależy wtedy od rzeczywistej natury obiektu, a bardziej od pragnień i potrzeb podmiotu. Infantylny strach przed obcymi zostaje wypełniony wyobrażeniem nieczystej grupy, postrzeganej stereotypowo. Żydzi w tym ujęciu są formacją

T.W. Adorno Osobowość autorytarna, s. 1. 
zastępczą dla „czarnego luda”, którego boją się dzieci. Ważne jest to, abyśmy sobie uświadomili,że podmiot uprowadzony przez stereopatię nie jest zdolny do przeżywania. Faszyzm jest ściśle związany z destrukcją doświadczenia. Nie sposób skorygować przeświadczeń stereopaty przez doświadczenie lub dostarczenie mu informacji. Pracując z taką jednostką, należy raczej na nowo wytworzyć zdolność do gromadzenia doświadczeń, aby w ten sposób zapobiec nadprodukcji fantazmatów.

Co zatem jest cechą charakterystyczną konstrukcji protofaszystowskiej podmiotowości? Otóż wydaje się, że - zdaniem Adorna - w tej konstrukcji superego staje się „rzecznikiem id”. Przypomnijmy raz jeszcze naukę Freuda - „symptom to oznaka lub zastępstwo niezrealizowanego zaspokojenia popędu, to sukces procesu wyparcia". Podbój superego przez id, dokonujący się w osobowości faszystowskiej, wiąże się z nieświadomym poczuciem winy, które musi zostać stłumione. Stereopata ciąży w kierunku „psychologicznego totalitaryzmu”, czegoś, co wydaje się "miniaturowym obrazem totalitarnego państwa”. W tym państwie wszystko musi zostać zrównane z „ideałem ego" mechanicznie zaprojektowanej grupy, z którą podmiot się identyfikuje. Destrukcyjność jest w pełnym tego słowa znaczeniu „totalitarna”.

Ponówmy naszą diagnozę: to faszyzm definiuje obszar psychiczny mogący być wykorzystany do jego celów, a nie na odwrót. Dlatego Adorno dodaje przytomnie, że żyjemy w czasach potencjalnie faszystowskich. Co to oznacza? Oznacza to, że osobowość można rozpatrywać jedynie jako jeden z czynników czegoś, co Adorno nazywa „całościowym schematem ideologicznym”. Co zawiera ten całościowy schemat ideologiczny? Z jakich konkretne treści się składa? Tym razem chodzi głównie o treści ekonomiczne i polityczne.

\section{Faszyzm jako schemat ideologiczny}

Zacznijmy raz jeszcze od bardzo ogólnego przesądzenia. Kapitalizm przez wiele lat przekraczał wszelkie ograniczenia i otwierał przed ludźmi możliwości. Obecnie jednak blokuje krytyczne perspektywy, które u jego początku były traktowane jako „postępowe”. W dzisiejszej formie jawi się jako potencjalnie niebezpieczny i reakcyjny. Kapitalizm wcale nie jest systemem zrodzonym z wolności, ale stanowi formację ściśle autorytarną. Nosi w sobie zarodki rozkwitu faszyzmu. To rozpoznanie Adorna zaskakuje, ponieważ zdaniem autora Teorii estetycznej faszyzm często cechuje się efektywnością organizacyjną i może się pochwalić osiągnięciami technologicznymi, a więc ma wiele cech „postępowych”. Nowoczesny faszyzm nie jest w kontrze do 
nowoczesności, lecz wykorzystuje progresywne i technologiczne cechy nowoczesności. To symbioza nowoczesności i idolatrii.

Jakiego rodzaju treści zawiera ta idolatria? To idolatria towaru, która daje efekt w postaci uogólnionego fetyszyzmu towarowego i reifikacji. Czym karmi się podmiotowość faszystowska? Jakie poglądy na politykę i ekonomię zawiera mózg faszysty? Wydaje się, że jedną z najistotniejszych w procesie formowania faszyzmu jest postawa wobec podatków. Jak pisze Adorno, podatki stanowią dokładnie ten punkt, który skupia na sobie całą społeczną agresję. Protofaszyści nie pojmują po prostu idei umowy społecznej i natury podatków oraz jej zasady. Adorno jest skłonny uznać to za „kompleks podatków", ujawniający właściwą pobudkę charakteru. Posuwa się nawet do stwierdzenia, że ktoś, kto skarży się na wysokie podatki, jest „naturalnym kandydatem" do ruchu o charakterze totalitarnym ${ }^{13}$.

Dlaczego podatki działają niczym test Rorschacha? No cóż, głównie dlatego że podatki nie tylko kojarzą się z rozrzutnym rządem demokratów, który wydaje miliony na "leni i biurokratów", ale przy tym temacie ludzie czują, że ten świat tak naprawdę nie należy do nich. Podatki to symbol państwa-Lewiatana. Korzyści, jakie jednostki mogą wyciągnąć z płacenia podatków, są dla protofaszysty niezrozumiałe. Jest on w stanie dostrzec jedynie to, że musi dać coś z siebie, nie dostając nic w zamian. Adorno dodaje: „Naziści wiedzieli bardzo dobrze, jak wykorzystać kompleks «pieniędzy podatnika»"14. W pierwszych latach rządów posunęli się aż do wspierania czegoś w rodzaju amnestii podatkowej, spopularyzowanej przez Göringa. W momencie gdy zmuszeni byli wprowadzić wyższe podatki niż kiedykolwiek wcześniej, bardzo umiejętnie ten fakt kamuflowali, robiąc to pod hasłem dobroczynności, dobrowolnych datków itd., a także „gromadząc duże sumy pieniędzy raczej na drodze nielegalnych gróźb niż oficjalnej legislacji podatkowej"15. Nie inaczej jest i dzisiaj. Fundacje, sponsorzy, dobroczynność - to nie tyle wynalazki faszystów, ile ich nagie instrumenty

Co zatem z polityką? Kluczowy wydaje się stosunek do komunizmu, który ujawnia tutaj „demoniczne” znamiona, choć nigdy nie ujawnia swego rzeczywistego znaczenia. Adorno pisze bardzo szorstko i analitycznie: im bardziej pojęcie komunizmu zostaje wyprane z wszelkich szczegółowych

Tamże, s. 264 .

14 Tamże, s. 263. 
treści, tym łatwiej przekształca się w poręczne opakowanie dla wszelkiego rodzaju wrogich projekcji. Nad ludźmi zaczyna krążyć widmo ekonomicznego supraindywidualizmu, jak gdyby komuniści rościli sobie prawo do własności najbardziej osobistych przedmiotów. Nienawiść do enigmatycznego komunizmu współgra z pogardą dla prawdy i uznaniem polityki za sferę pozbawioną prawdy. To pozbawienie polityki znamion prawdy jest powiązane także z religią, która ulega neutralizacji. Religia w tej interpretacji ma dostarczać jedynie odpowiedzi na potrzebę posiadania „czegoś, czego można się trzymać”. Tę potrzebę może zaspokoić absolutny autorytet wodza. Adorno konkluduje: „Nie przypadkiem nazizm zakiełkował w południowych Niemczech, gdzie istnieje silna tradycja rzymskokatolicka"16. Neutralizacji religii towarzyszy swoista dekompozycja wiary. Tworzy się państwo pseudoateistów, cyników. To, co w XVIII stuleciu było jednym z impulsów oświecenia, dziś okazuje się świadectwem sekciarstwa i konformizmu.

Podsumowałbym tę część stwierdzeniem, że protofaszyści nawołują do obrony demokracji przeciwko jej "nadużyciom”, a atakując "nadużycia”, chcą ostatecznie obalić samą demokrację. Pytanie brzmi: czy istnieje coś takiego jak osobowość potencjalnie faszystowska par excellence, która stanowi „strukturalną jedność"? Adorno odpowiada na to pytanie twierdząco. Oznacza to, że wbrew stworzonej przez siebie bogatej typologii konstrukcji antydemokratycznych uznaje jednocześnie, że takie cechy, jak konwencjonalność, podporządkowanie, agresja, skłonność do projekcji, brak obsadzeń libidinalnych, stereopatia tworzą spójną strukturę. Kluczowe znaczenie ma zatem kwestia, czy Adorno nie ryzykuje tym zaanektowaniem polityki przez psychoanalizę zgubienia różnicy dzielącej „ludzi gotowych na faszyzm” w demokracji i ludzi jawnie zdeklarowanych jako faszyści, takich jak Adolf Eichmann chociażby. Czy Adorno widzi w nowoczesnym człowieku, tj. produkcie przemysłu kulturalnego, będącego przecież celem dążeń liberalizmu, tylko materiał antropologiczny, gotowy, by stać się czystym zasobem nagiej biopolityki?

\section{Banalność faszyzmu albo danie jednogarnkowe}

Adorno jeszcze w 1951 roku pisał zupełnie jasno, że faszyzm, aby stać się skutecznym ruchem politycznym, musi zyskać poparcie w masach ${ }^{17}$. Faszyzm nie może się opierać jedynie na represji i podporządkowaniu, lecz wymaga

16 Tamże, s. 286.

17 T.W. Adorno Freudowska teoria i model propagandy faszystowskiej, s. 185-211. 
aktywnej współpracy zdecydowanej większości ludzi. Jak dochodzi do takiego wsparcia lub współpracy większości? Jak możliwa jest ta współpraca i co ona zakłada? W jakim sensie ludzie pragną faszyzmu? Adorno pisze czasem tak, jakby obywatele demokracji zachodnich zostali oszukani przez demagogów, inżynierów dusz, którzy organizują faszyzm. Czasem jednak można odnieść z lektury wrażenie, że faszyzm wypływa wprost z pragnień ludzkich, jakby głównym obiektem ludzkiego pragnienia demokraty było stanie się faszystą. Jak to wyjaśnić? Czy mamy tu oczywistą sprzeczność?

Zapytajmy na początek, co robi demagog? Wytwarza on sztuczne więzi, formuje fałszywą organizację. Dlaczego to robi? Na to pytanie precyzyjnie odpowiedział już Freud w Massenpsychologie und Ich-Analyse - tekście z 1921 roku ${ }^{18}$, poświęconym analizie dwóch wielkich i sztucznych zbiorowości armii i Kościoła. Twierdzi tam, że utrata poczucia indywidualnej odrębności stanowi doznanie rozkoszy. Rozpuszczenie osobowości należy traktować jako źródło i mechanizm produkcji rozkoszy. Z tej produkcji rodzi się faszyzm. Faszyzm rodzi się z rozpuszczenia swojego „ja” w masie.

Pytam raz jeszcze: kim jest zatem demagog? Adorno słusznie odpowiada, że nie ma żadnej tajemnicy ani uroku Goebbelsa, Hitlera czy Göringa. Jest tylko banał ich nieświadomości. Co to oznacza? Oznacza to, że agitator zwraca ku innym swoją nieświadomość i w ten sposób kieruje się w stronę dyspozycji słuchacza. Adorno mówi wprost - Hitler nie wchodził w rolę kochającego ojca, ale raczej groźnego Superego lub raczej Supermana, którego się kocha, tylko jeśli on sam nie kocha nikogo. Agitator to Superman z kiosku, jest inny i przeciętny, , agitator to kombinacja King Konga i fryzjera z przedmieścia”’ W istocie istnieje ścisły związek pomiędzy faszyzmem, okultyzmem, mesmeryzmem i dyspozycją do użycia hipnozy w celach politycznych. Nie zmienia to faktu, że faszystowski hochsztapler to nieskończony banał i tajemnica w stopniu zero. Być może z tego powodu tak trudna okazuje się intelektualna analiza faszyzmu. Możliwa jest tylko psychoanaliza. Psychoanaliza jest wprost stworzona do analizy polityki faszyzmu. Tak jakby była ona niechcianą bliźniaczką faszyzmu.

We Freudowskiej teorii i modelu propagandy faszystowskiej Adorno próbuje opisać sylwetkę agitatora politycznego, faszystowskiego demagoga, który przekształca lud w motłoch, wytwarza masę skłonną do przemocy, której

18 S. Freud Psychologia zbiorowości i analiza ego, przeł. J. Prokopiuk, w: tegoż Poza zasadą przyjemności, Wydawnictwo Naukowe PWN, Warszawa 1997, s. 191-257. 
symbolem jest danie jednogarnkowe, Eintopfricht. Adorno pisze ponownie o zniesieniu demokracji przez masowe poparcie skierowane przeciwko zasadzie demokracji. Co to oznacza dla niego tym razem? To, że cele faszyzmu są jednak popędowe, a nie ściśle ekonomiczne. Faszyzm uważa ludzi za to, czym de facto są. Ludzie masowej demokracji to dzieci współczesnej kultury masowej, kukiełki pozbawione autonomii, nie-jednostki czy raczej - anty-jednostki. Faszyzm w tym opisie przychodzi „po liberalizmie”, czyli w epoce „po jednostce”, gdy psychologia jednostki straciła wszelki sens, tj. kiedy psychologia, nie będąc źródłem faszyzmu, stała się jednym z elementów systemu. Freud mógł tylko napisać analizę „ja” jako psychologię zbiorowości, nie był zaś zdolny napisać psychologii zbiorowości jako analizy ego.

\section{Faszyzm jako perwersja stadnego pragnienia}

Taki sposób myślenia o faszyzmie może budzić wątpliwości, a nawet sprzeciw. Można bowiem argumentować, że mamy dzisiaj mocniejsze lub bardziej czułe sposoby myślenia o dyspozycjach faszystowskich. Szczególnie Gilles Deleuze i Felix Guattari wypracowali metody myślenia, zgodnie z którymi masy nie zostały oszukane przez faszyzm, one po prostu pragnęły faszyzmu ${ }^{20}$. Faszyzm jest tu zatem pojmowany jako perwersja stadnego pragnienia, a nie tylko zbiorowej hipnozy.

Z punktu widzenia schizoanalizy pragnienia nie da się oszukać, choć da się je wyprodukować. Oszukać można jedynie interes. Faszystowski hipnotyzer może oszukiwać, tj. uznawać, negować lub podjudzać interesy, lecz nie może tego samego zrobić z pragnieniem. Wbrew temu, co pisze czasem Adorno, masy nie zostały oszukane, one pragnęły faszyzmu, i to pragnienie właśnie należy wyjaśnić. Jest to pragnienie, z którego kapitalizm potrafi skorzystać, szczególnie kiedy „technologia” i inżynieria społeczna utrzymują, że działają same z siebie, a zatem w epoce pełnego automatyzmu, tak jakby automatyzacja i faszyzm podążały ręka w rękę. Wydaje się, że gdy Deleuze i Guattari piszą, iż „faszyzm jest tylko zarysem, postacią jest post-faszyzm”21 i kiedy przepowiadają nadejście „jakiegoś uogólnionego faszyzmu”, faszyzmu, który jeszcze nie osiągnął szczytu i rozwija się dalej, to w jakimś sensie zrównują

20 G. Deleuze, F. Guattari Anty-Edyp. Kapitalizm i schizofrenia, przeł. T. Kaszubski, Wydawnictwo Krytyki Politycznej, Warszawa 2017, s. 301 i 460. 
faszyzm i liberalizm, albo jak powiedziałby Adorno - libidinalne warunki faszyzmu z samym faszyzmem.

Dla autorów Tysiąca plateau fantazmat jest zawsze rozpięty pomiędzy faszyzującym biegunem paranoi a rewolucyjnym biegunem schizofrenii i nigdy nie mamy pewności, czy wychyli się on w stronę paranoi czy schizofrenii. Pomiędzy biegunem paranoi i schizofrenii jest być może ulokowany liberalizm. Powiedzieć, że „faszyzm jest urzeczywistnionym nihilizmem”, to przecież powiedzieć, iż pragnienie szuka nicości i samo pragnienie jest skonstruowane w obszarze niczego. U Deleuze'a i Guattariego nie ma pragnienia, są tylko maszyny pragnienia, konstrukcje pragnienia.

Jest rzeczą niezwykle intrygująca, że gdy Michel Foucault w Narodzinach biopolityki określa liberalizm jako „słowo, które pochodzi z Niemiec”, w jednym $\mathrm{z}$ wykładów precyzyjnie rekonstruuje narodziny liberalizmu niemieckiego z ducha faszyzmu. Opowiada o liberalizmie po faszyzmie ${ }^{22}$. Przyglądając się poglądom przedstawicieli „ekonomii narodowej”, tj. ordoliberałom, myślicielom takim jak Alexander Rüstow, Wilhelm Röpke, Friedrich August von Hayek, Walter Eucken, Ludwig Wilhelm Erhard, zestawia ze sobą szkolę z Freiburga ze szkołą frankfurcką, mówi o przemieszczeniu problemu Marksa i weberyzmie obu szkół. Autor Nadzorować i karać twierdzi, że niemiecka refleksja socjologiczna, ekonomiczna i polityczna po wojnie chciała wyjaśniać irracjonalność kapitalizmu nie tyle w kategoriach sprzeczności samego kapitału, ile raczej w kategoriach „irracjonalnej racjonalności” społeczeństwa kapitalistycznego jako całości. Problemem dla szkoły frankfurckiej było ustalenie, jaką racjonalność przeciwstawić „irracjonalności ekonomicznej”. Szkoła fryburska natomiast próbowała przeciwstawić na nowo odkrytą „racjonalność ekonomiczną” „społecznej irracjonalności kapitalizmu”. W obu przypadkach jednak diagnoza faszyzmu miała ujawnić prawdę ekonomii, prawdę liberalizmu. W obu faszyzm ujawniał prawdę polityki ekonomicznej.

Dla Foucaulta niemieccy ordoliberałowie nie postrzegają nazizmu jako potworności lub aberracji. Mówią raczej: nazizm jest prawdą o ekonomii politycznej. Dodają także: nazizm ujawnia system relacji między różnymi elementami tworzącymi polityczną nadopiekuńczość państwa. Choć Foucault zdaje sobie sprawę, że totalitaryzm nie wynika z rozrostu państwa, lecz z jego pomniejszenia na rzecz partii, i stale przypomina, iż państwo totalitarne to nie jest ani państwo administracyjne, ani państwo policyjne, ale 
„coś innego". Niemniej dodaje, że - zdaniem ordoliberałów - funkcjonowanie „wariantu antyliberalnego" wymaga nie tyle państwa, ile nadpaństwa, naddatku państwa, albowiem tradycyjne formy państwa nie są w stanie sprostać nowym wyzwaniom ekonomicznym. Foucault nie szczędzi też ironii zastosowanej wobec Adorna i jego formacji intelektualnej, pisząc: „historia sprawiła, że ostatni uczniowie szkoły frankfurckiej zmuszeni zostali, w 1968 roku, do wezwania policji służącej rządowi, który inspirował się teoriami z Fryburga. W ten sposób przeszli na drugą stronę barykady. Zgodnie z podwójnym, równoległym, splątanym i naznaczonym konfliktem przeznaczeniem niemieckiego weberyzmu" ${ }^{23}$. Wygląda na to, że w tej formie faszyzm to model analityczny niezbędny do przemyślenia historii kapitalizmu i liberalizmu w Europie. Zapomnienie Marksa to zapomnienie skutkujące zaniechaniem myślenia o ekonomii w kategoriach sprzeczności kapitalizmu i nieuniknionego konfliktu klasowego.

Wykonajmy na tej mapie faszyzmów jeszcze jeden ruch. Roberto Esposito w celu zrozumienia tym razem nazizmu nie analizuje ukrytych dyspozycji osobowościowych ani poglądów ekonomistów liberalnych, ale czyta traktaty uczonych filologów XIX stulecia, tj. poddaje analizie poglądy takich językoznawców, jak August Schleicher, Max Müller, Honoré-Joseph Chavée, Georges Vacher de Lapouge, którzy piszą o związku rasy i języka oraz przyczynach degeneracji języków. Z jego punktu widzenia, wbrew naszym oczekiwaniom, nazizm nie zawęża wcale pojęcia ludzkości oraz kategorii humanitas. W obrębie nazizmu następuje raczej „humanizacja zwierząt wyższych”, nad których wartością należy stale pracować, oraz „zezwierzęcenie postaci ludzkich” uznanych za zdegenerowane ${ }^{24}$.

Naczelne pojęcia nowej polityki to domestykacja (Zähmung), hodowla (Züchtung), kultywacja (Anbau), sztuczna selekcja (Auslese), wreszcie ekstrakcja i wykorzenienie (Ausmerzung) ${ }^{25}$.Wszystkie te pojęcia świadczą o głębokiej potrzebie renaturalizacji natury. Nowatorstwo nazizmu wynika nie tyle z „filozofii ucieleśnionej” czy „ucieleśnionej ideologii”, ile z ucieleśnionej i w pełni „urzeczywistnionej biologii”. Nazizm próbował „poprawić naturę" drogą sztucznej selekcji; naturalna selekcja jest szkodliwa, albowiem doprowadza

23 Tamże, s. 124 .

24 R. Esposito Pojęcia polityczne. Wspólnota, immunizacja, biopolityka, przeł. K. Burzyk, M. Burzyk, M. Surma-Gawłowska, J.T. Ugniewska-Dobrzańska, M. Wrana, Universitas, Kraków 2015.

25 R. Esposito Third person: politics of life and philosophy of the impersonal, przeł. Z. Hanafi, Polity Press, Cambridge 2012. 
do krzyżowania się ras oraz nieprzewidywalnych mutacji, te zaś szkodzą czystości ras. Nazizm w tym ujęciu jest fantazją na temat natury poza zdegenerowaną naturą, fantazją na temat człowieka w raju, który nie został jeszcze skazany na reprodukcję przez krzyżowanie ras.

Czas na krótkie podsumowanie. Mamy zatem postfaszyzm jako liberalizm (Deleuze, Guattari), liberalizm po faszyzmie (Foucault) i wreszcie faszyzm w liberalizmie (Adorno). Mamy na koniec janusowe oblicze biopolityki Esposita - liberalizm i nazizm jako dwie twarze polityki rozumianej jako ucieleśniona biologia. Pytam raz jeszcze: czy dysponujemy jednolitym pojęciem faszyzmu, czy też skazani jesteśmy jedynie na jego wielorakie obrazy, impresje? Czy te wielorakie impresje tworzą jednak zarys jakiegoś pojęcia? I czy brak pojęcia faszyzmu nie skazuje nas na jego powroty? Nie możemy pojęciowo związać faszyzmu, dlatego pozostaje on stale symptomem, zastępstwem niezrealizowanego popędu, sukcesem procesu wyparcia.

\section{Faszyzm bez wiary w siebie albo blizny demokracji}

Zacznijmy raz jeszcze od pytania: czym są powroty faszyzmu? W jakim celu Adorno wraca do faszyzmu i poruszanie tego tematu traktuje jako swój naczelny obowiązek? O co chodzi, gdy mowa o nowym prawicowym radykalizmie? I dlaczego wyrażenie „nowy prawicowy radykalizm”26 ponownie ukrywa faszyzm, tak jak niegdyś to pojęcie było ukryte pod wyrażeniem „osobowość autorytarna"? Dlaczego Adorno, który wygląda na człowieka stworzonego do tego, aby słuchać muzyki Gustava Mahlera i Wolfganga Amadeusza Mozarta, musi stale prześladować siebie i świat mową na temat faszyzmu, który nie chce zniknąć?

Jedno sprostowanie. Adorno nigdy nie będzie analizował postfaszymu, tj. sytuacji, w której antysemityzm przeradza się w islamofobię, a brunatne koszule i wodzowskie formacje w ruchy populistyczne. O tym będzie mówił Enzo Traverso, który podejmie się analizy ruchów pasożytujących na deficytach demokratycznych w europejskich organizacjach opartych na multikulturalizmie $^{27}$. Adorno bada raczej możliwość prawicowego radykalizmu, a ściślej rzecz biorąc, sprawdza warunki pozwalające na dalsze trwanie tendencji, które doprowadziły lub mogą doprowadzić do faszyzmu. Co to są za warunki?

26 T.W. Adorno Nowy prawicowy radykalizm.

27 E. Traverso Nowe oblicza faszyzmu. Rozmowy z Régisem Meyranem, przeł. Z.M. Kowalewski, Instytut Wydawniczy „Książka i Prasa”, Warszawa 2020. 
Wracamy raz jeszcze do kapitalizmu i jego tendencji do koncentracji kapitału, oznaczającej możliwość deklasacji warstw społecznych, które pozostają mieszczańskie i pragną zachować swoje przywileje oraz status grup uprzywilejowanych. To zagrożenie monopolizacją kapitału oznacza przede wszystkim zagrożenie zubożeniem. Mieszczaninowi jako faszyście grożą stałe niebezpieczeństwo inflacji i widmo bezrobocia wywołanego postępem technicznym, które zostanie wzmocnione w czasie pełnej automatyzacji. Kapitalizm rodzi populację ludzi potencjalnie bezrobotnych i zbędnych. Inaczej mówiąc, w późnym kapitalizmie narody w pierwszym kroku zamieniają się w odbiorców zapomóg, a w kroku drugim w zastępy zwolenników ruchów autorytarnych. W ten sposób budzi się lęk przed Europejską Wspólnotą Gospodarczą i wywołuje warunki powrotu czegoś, co Adorno nazywa „fikcyjnym nacjonalizmem", czyli nacjonalizmem, w który nikt już nie wierzy. Oto faszyzm, który już niczego nie wytwarza, nie tworzy więzi, nie jest nawet ruchem. Jest tylko pasożytem, rakiem, blizną po demokracji.

Taka konstelacja skutkuje nowym etapem rozwoju radykalizmu prawicowego, który można by nazwać demonicznym, widmowym lub wirtualnym. Tego widmowego radykalizmu powinniśmy się bać bardziej niż radykalizmu realnego, materialnego. W czasie radykalizmu bezobiektowego lub widmowego, tj. „wystawnego nacjonalizmu patetycznego", ideologie przybierają postać demoniczną i destrukcyjną. Adorno jako historyk przypomina, że procesy czarownic nie toczyły się w szczytowym okresie rozwoju tomizmu, lecz w czasach kontrreformacji. Fundamentalną kwestią dla nowej prawicy jest wysiłek dopasowania się do głównego nurtu, tj. odrzucenie „jawnej antydemokratyczności"28. Oto raz jeszcze faszyzm jako ruch antywolnościowy, który przedstawia się jako jedyny obrońca wolności.

Tym razem istotne w rozumowaniu Adorna jest powiązanie faszyzmu nie tyle z kapitalizmem, ile z demokracją. Pisze wprost: główną przesłanką powrotu faszyzmu jest to, że demokracja nigdy nie stała się demokracją realną. Żyjemy w pozornych demokracjach, tj. demokracjach tylko z imienia, legitymizowanych przez odwołanie się do procedur wyborczych. Dla Adorna do dziś nie wykształciła się ani jedna rzeczywista demokracja w sensie społeczno-ekonomicznym. Nawet demokracja w Ameryce nie jest demokracją realną. Demokracje są nimi wyłącznie formalnie. „I w tym sensie - dodaje Adorno - ruchy faszystowskie można by określić mianem ran czy też blizn demokracji, która do dzisiaj nie była w stanie zadośćuczynić własnemu

28 T.W. Adorno Nowy prawicowy radykalizm, s. 10. 
pojęciu"29. Pojęcie faszyzmu byłoby zatem ściśle powiązane z pojęciem demokracji. Enigmatyczność pojęcia demokracji rodziłoby enigmatyczność pojęcia faszyzmu.

Tym razem nie mówi jako apokaliptyk, fantazmatyk lub alegoryk. Trzeźwy Adorno przestrzega przed dyskursem apokaliptycznym. Autor Minima Moralia przestrzega: radykalne ruchy wyzwalają dyskurs apokaliptyczny, karmiąc się fantazjami o końcu świata i równocześnie prezentując siebie jako rodzaj „maszyny opatrznościowej”, udając, że są gwarantami przyszłości. Oto radykalizm, który w siebie nie wierzy: widmo widma ${ }^{30}$. Oto radykalizm, który nie opiera się już na spontanicznym ruchu masowym. Nowe grupy promujące radykalizm stają się antyczarne i antyczerwone, przez walkę na dwa fronty stają się „nową równowagą”, „radykalizmem centrum”. Oto faszyzm, który opiera się na zestawie prostych trików, technice aluzji, manipulacji na materiale, retoryce, która rozmyśla nad tym, czego nie można powiedzieć.

Adorno raz jeszcze podkreśla, że prawicowy radykalizm nie jest tylko problemem psychologicznym czy ideologicznym, lecz w najwyższym stopniu problemem realnym i ściśle politycznym ${ }^{31}$. Autor Dialektyki oświecenia bardziej jako świadek swoich czasów, a mniej jako zimny analityk polityczny przestrzega, że dalsze życie narodowego socjalizmu „w demokracji” jest czymś "dużo bardziej niebezpiecznym od dalszego życia faszystowskich tendencji przeciwstawionych demokracji"32. Radzi także, by nie uważać faszyzmu za „nieunikniony kataklizm”. Faszyzmu nie należy traktować jako „obiektu kontemplatywnego". Jeśli na kwestie polityczne patrzy się jak na katastrofy tonu apokaliptycznego w filozofii. Pyta, kim są współcześni mistagodzy. I odpowiada: są oni magami nowej inicjacji, wprowadzania w tajemnicę, to kapłani fałszywego oświecenia, którzy uwodzą poprzez tajemnicę. Derrida widzi w tym wyniosłym tonie w filozofii agogiczną funkcję prowadzenia ludzi, funkcję Duce, Führera, przywódcy, wynoszonego ponad tłum, którym manipuluje przy pomocy zwolenników zrzeszonych w sektę posługującą się zaszyfrowanym językiem. Mówi o popędzie panowania (Bemachtigunstrieb), oraz domaga się Verstimmung mnożącego głosy i sprawiającego, że ton się zmienia. Verstimmung to umożliwienie innemu tonowi, tonowi pochodzącemu z zewnątrz, na dokonanie zmiany. Verstimmmung to wykolejenie, nagła zmiana tonu, zmiana nastroju, rozstrojenie, a zarazem możliwość każdej emisji (J. Derrida O apokalipsie, przeł. I. Boruszkowska, K. Wojtasik, Wydawnictwo Eperons-Ostrogi, Kraków 2018). 
naturalne $\mathrm{i}$ „w odniesieniu do nich tworzy przewidywania niczym o tornadach albo innych katastroficznych zjawiskach pogodowych, [to] tkwi [w tym] już pewnego rodzaju rezygnacja, odbierająca nam w zasadzie status podmiotów politycznych" ${ }^{\text {"33 }}$. Naturalizowanie faszyzmu jest błędem.

Nie wystarczy jednak samo uhistorycznienie faszyzmu. Nie wystarczy odebranie mu statusu „obiektu naturalnego". Rodzi się potrzeba interwencji w tkankę faszyzmu. Wyłania się zatem pytanie, jak można interweniować w faszyzm. Jak można zareagować na faszyzm? Jeśli autorytarne charaktery są nieresponsywne w tym znaczeniu, że są niezdolne do odpowiedzi, to czy niefaszysta jest jednostką zdolną do wolnej reakcji na faszyzm i przeciw faszyzmowi? W końcowych fragmentach Osobowości autorytarnej Adorno porównuje sylwetkę autentycznego liberała do Freudowskiego typu erotycznego - można go postrzegać w kategoriach równowagi między superego, ego i id. To jednostka, która jest zdolna do miłości, autonomii i unika za wszelką cenę narcyzmu. Czy jednak powiązanie liberalizmu i faszyzmu oraz rozpoznanie w demokratach ludzi gotowych na faszyzm nie unieważnia naszej liberalnej wiary w istnienie tego rodzaju osób otwartych na komunikację z własnymi impulsami płynącymi z id, ludzi niepozwalających superego na odniesienie sukcesu z procesu wyparcia?

Adorno już w Minima Moralia polemizuje z tym liberalnym samozadowoleniem, pisząc, że pogląd, jakoby artyści nie zaspokajali popędów ani ich nie wypierali, lecz przemieniali w społecznie pożądane działania, to "psychoanalityczna iluzja”. Dzieła Mozarta i Mahlera są przepełnione „brakiem zahamowań”,,narcyzmem posuniętym do granic paranoi”,,idiosynkrazjami”. Adorno pisze zuchwale: „Do teorii Freuda nie pasują, ponieważ teorii tej brak odpowiedniego pojęcia ekspresji. [...] Ekspresja neguje rzeczywistość, bo występuje z czymś, co nie przypomina rzeczywistości, ale nie zaprzecza jej; patrzy prosto w oczy konfliktowi, który w symptomie rozgrywa się na ślepo"34. Czy będziemy zatem skazani na faszyzm tak długo, jak długo będzie nam brakować pojęcia ekspresji i jak długo o ekspresji będziemy myśleć w kategoriach sublimacji? W jakich relacjach pozostają do siebie ekspresja i rzeczywistość? Przypominam raz jeszcze diagnozę Freuda: symptom - zastępstwo niezrealizowanego zaspokojenia popędu, to sukces procesu wyparcia. Czy w XX wieku obserwujemy coś innego niż tylko kolejne sukcesy procesu wyparcia?

33 34

Tamże, s. 49. T.W. Adorno Minima Moralia. Refleksje z poharatanego życia, przeł. M. Łukasiewicz, Wydawnic-
two Literackie, Kraków 1999, s. 256 . 


\section{Nieprzedstawialność faszyzmu albo sensacja absolutna}

W przywołanych wcześniej Minima Moralia Adorno nawoływał do wywodzenia faszyzmu ze złych wspomnień z dzieciństwa. Tak jakby w faszyzmie koszmar dzieciństwa doczekał się po prostu spełnienia. Wydaje się, że Adorno nie zmierza tylko do odzyskania obrazu faszyzmu poprzez obrazy dzieciństwa, ale raczej jego celem jest coś znacznie bardziej złożonego, tj. stwierdzenie, że faszyzm przychodzi „po mieszczaństwie”, zachowując mieszczańskie formy egzystencji. Faszyzm karmi się upadkiem ekonomicznych podstaw mieszczaństwa. Faszyzm jest mieszczaństwem w ruinie. Mieszczanie w ruinie, analizowani przez Adorna, utracili naiwność i zrobili sięźli. Pisze on złowieszczo: „Mieszczanie żyją dalej jak groźne upiory zguby”35. Czym skutkuje upiorność mieszczaństwa dla upiorności faszyzmu? Adorno dopisuje: „Hitler jak żaden inny mieszczanin umiał przejrzeć nieprawdę liberalizmu, ale nie przejrzał ukrytej za nim mocy [...]. Głupota Hitlera była chytrością rozumu"36. Czy chytrość rozumu to po prostu liberalna chytrość biopolityki, która tym się różni od faszyzmu, że zamiast niszczyć ideę wolności, podtrzymuje jej iluzję lub wprost ją wytwarza, produkuje wolność, aby nią zarządzać. To wolność ludzi jako roślin cieplarnianych ${ }^{37}$.

Otóż Adorno pisze coś na pierwszy rzut oka niezrozumiałego, konstatując "nieprzedstawialność faszyzmu”. Ta nieprzedstawialność wynika $\mathrm{z}$ tego, że faszyzm unicestwia wolność - zarówno po stronie obserwatorów, jak i aktorów. Nikt nie widzi faszyzmu. Faszyzm jest niejawny. Nawet

Tamże, s. 32.

Tamże, s. 122.

Jest rzeczą godną uwagi, że rozpoznania Adorna znakomicie korespondują z analizami i wypowiedziami Piera Paola Pasoliniego, zdaniem którego nie należy zachowywać się w stosunku do faszystów „w sposób rasistowski”, tj. pochopnie uznawać, że faszyści są predestynowani do bycia faszystami. Przyjęcie, że istnieje predyspozycja faszystowska, skutkowało jedynie polityczną impotencją, tj. uznaniem, iż w obliczu faszyzmu nic się nie da zrobić. Pasolini pisze explicite o nowym i starym faszyzmie. Stary faszyzm pozostawał w koalicji z klerykalizmem i nacjonalizmem, ustępuje jednak miejsca nowemu faszyzmowi, opartemu na telewizji i nowoczesnej technologii. „Ponieważ stary faszyzm, choćby nawet przez retoryczną degenerację, pozwalał się odróżnić, gdy tymczasem nowy faszyzm - który jest czymś zupełnie innym - już się nie odróżnia: nie jest humanistycznie retoryczny, jest po amerykańsku pragmatyczny. Jego celem jest reorganizacja i brutalnie totalitarna homogenizacja świata" (P.P. Pasolini Prawdziwy faszyzm, a zatem prawdziwy antyfaszyzm, przeł. A. Osmólska-Mętrak, w: tegoż Po ludobójstwie. Eseje o języku, polityce i kinie,: Kronos, Warszawa 2012, s. 245). Dla Pasoliniego akceptacja faszyzmu była potwornym epizodem; akceptacja burżuazyjnej cywilizacji jest faktem definitywnym. 
nie w tym znaczeniu, że opiera się na publicznym sekrecie, ale w tym, że nie pozostawia miejsca na niezainteresowanego obserwatora. "Całkowite zniewolenie - dodaje Adorno - można rozpoznać, ale nie można go przedstawić"38. Oznacza to, że samo mieszczaństwo wytwarza nowy narząd, który Foucault nazwałby władzą nadzoru nad życiem, tj. urządzeniem bezpieczeństwa. Dla Adorna ten "nowy narząd” wytwarza ścisłą organizację życia, wymagającą „zrzeszenia ludzi martwych”. „Wola życia skazana jest na negację życia: samozachowanie anuluje życie podmiotowe"39. Faszyzm jest w tym ujęciu „sensacją absolutną". „Sensacją w znaczeniu pierwotnym - jako sensation Johna Locke'a czyli przeciwieństwo refleksji". Faszyzm zmierza do ostatecznego rozpalenia osłabionego sensorium mas. Stąd jego sentyment do okultyzmu. Stąd też jego antyintelektualizm. Faszyzm to śmierć intelektu. Intelekt jest niezbędny do przedstawienia, intelekt jest organem prezentacji.

Adorno podpowiada, że w społeczeństwie bez wolności samo pojęcie człowieka jest tylko parodią idei podobieństwa. „Mord jest wówczas próbą, by w rozumie zamaskować obłęd tej fałszywej percepcji przez obłęd jeszcze gorszy: co nie było postrzegane jako człowiek, a przecież jest człowiekiem, zostaje sprowadzone do rzeczy, aby już żadnym drgnieniem nie mogło odeprzeć maniakalnego spojrzenia"40. W kontrze do Nauki o podobieństwie i O zdolności mimetycznej Waltera Benjamina, Adorno nie widzi w podobieństwie siły mimetycznej, która osłabła, nie dostrzega już w języku „,kanonu niezmysłowego podobieństwa"41 . Jasnowidztwo nie przeniosło się ze sfery nieba do języka, lecz z języka do złej polityki. Mimetyczny aspekt polityki, na podobieństwo płomienia, tylko podpala. Tak oto kończy się zabawa w politykę jako zabawa zapałkami. To nie język, ale polityka jest sferą wzmożonego okultyzmu. Potrzebujemy tez przeciwko okultyzmowi. Potrzebujemy polityki, która nie odwołuje się do okultyzmu.

Czym jest zatem myśl niefaszystowska? Czym jest ekspresja, która nie pozostawałaby w służbie faszyzmu? Czy myśl niefaszystowska powinna się uwolnić od wszelkiego elementu paranoidalnego? Nie wydaje się. Adorno

\footnotetext{
38 T.W. Adorno Minima Moralia, s. 229.

39 Tamże, s. 276.

40 Tamże, s. 121.

41 W. Benjamin Konstelacje. Wybór tekstów, przeł. A. Lipszyc, A. Wołkowicz, Wydawnictwo UJ, Kraków 2012.
} 
pisze jasno, że myśliciel, któremu brakuje elementu paranoidalnego, jak np. Georg Simmel, nie znajduje nigdy oddźwięku i szybko zostaje zapomniany. "Gdyby zdefiniować prawdę jako to, co po prostu nieparanoiczne, prawda, której element stanowi praktyka, byłaby nie tylko bezsilna i skonfliktowana sama z sobą" ${ }^{42}$. Nieparanoiczna prawda nie stworzyłaby struktury sensu. Sama ucieczka przed fiksacją przeradza się w gonitwę myśli, a „myślenie oczyszczone z obsesji samo staje się obsesyjne”43. „Dialektyka to wysiłek ocalenia określoności teorii, bez popadania w obłęd"44. Faszyzm nie może zapanować nad gonitwą myśli dialektyka. To dialektyk musi zapanować nad „faszyzmem pojęcia” poprzez panowanie nad pojęciem faszyzmu.

Wróćmy na koniec do Freuda. W cytowanym już tekście Zahamowanie, symptom, lęk pisał on o nieświadomości, która nie zna śmierci, w której nie występuje nic, co mogłoby nadać treść pojęciu unicestwienia życia.

Kastracja jest, by tak rzec, czymś wyobrażalnym za sprawą codziennego doświadczenia odrywania się od treści odbytnicy i odzwyczajania się od przeżytej utraty piersi macierzyńskiej; nigdy jednak nie przeżyto stanu podobnego do śmierci, nigdy też coś w rodzaju niemocy nie pozostawiło po sobie dających się dowieść śladów. Dlatego pozostaję przy przypuszczeniu, że lęk przed śmiercią należy ujmować jako analogon lęku przed kastracją i że sytuacja, w której reaguje ja, sytuacja opuszczenia przez opiekuńcze nad-ja - przez moce losu - to chwila, w której dobiega kresu poczucie bezpieczeństwa przed wszystkimi niebezpieczeństwami. ${ }^{45}$

Sukces faszyzmu jako sukces procesu wyparcia wynika z tego, że jest on polityką nie tyle życia, ile śmierci. Faszyzm próbuje zarządzać lękiem przed śmiercią. Tak jak liberalizm zajmuje się produkcją wolności i zarządzaniem wolnością, tak faszyzm zajmuje się produkcją lęku i wytwarzaniem wyobrażeniowych urządzeń do tworzenia zastępczego poczucia bezpieczeństwa. Faszyzm jawi się jako opiekuńcze nad-ja, które daje ofertę poczucia bezpieczeństwa przed wszystkimi niebezpieczeństwami.

T.W. Adorno Minima Moralia. Refleksje z poharatanego życia, s. 311.

Tamże.

44 Tamże. 


\section{Faszyzm jako impresja albo interwencja}

Faszyzm nie był i nie jest incydentem. Życie Adorna było naznaczone przez erę faszyzmu. Jest dzieckiem napiętnowanym przez faszyzm. Jego pierwsza ważna książka, doktorat zatytułowany Kierkegaard:Konstruktion des Ästhetischen, ukazuje się w księgarniach 27 lutego 1933 roku, a zatem w „dniu dyktatora”, tj. dniu, gdy Hitler ogłosił stan wyjątkowy, zawiesił wolność prasy. To koniec czasu kanclerza i początek epoki dyktatora. To nie przypadek, że doktorat Adorna, w dużej części poświęcony konstrukcji estetycznej, jest jawną krytyką organicznej jedności ${ }^{46}$. Adorno żyje impresją faszyzmu. W jakim sensie?

W sensie, o jakim wspomniał Jacques Derrida, gdy zastępował słowo „pojęcie” słowem „impresja”, pisząc „impresję freudowską" ". Impresja musi zastąpić pojęcie, albowiem „pojęcie” wytworzy zamknięcie wszystkich „impresji" w jedynym futerale. Czym jest zatem impresja? Na czym polega wyższość impresji nad pojęciem? Po pierwsze, impresja to typograficzna inskrypcja - rodzaj Niederschrift, dolna czcionka maszyny do pisania, znamię na powierzchni. Po drugie, impresja to „fikcja”. Impresja to zmienne i nietrwałe odczucie figury, nieskończonego, nieokreślonego schematu. Po trzecie, impresja to naddrukowana treść wydruku: na-druk (le pression de l'impression) przed podziałem na to, co wydrukowane, i to, co drukujące. Adorno jest prześladowany przez impresje faszyzmu we wszystkich trzech znaczeniach tego słowa. Faszyzm nie jest symptomem, funkcją ani nawet schematem ideologicznym, ale jest znamieniem, raną w demokracji, jest także nieokreślonym wyobrażeniem pasterza uśmierzającego wszystkie nasze lęki. Faszyzm jest wreszcie nowoczesną postacią polityki pastoralnej ${ }^{48}$. Na koniec faszyzm jest wdrukowanym w demokrację znamieniem, czymś w rodzaju litej skały polityki.

Jeszcze słowo o interwencji. Adorno przypomina, że w roku 1945 w Niemczech, w przeciwieństwie do Włoch, nie było prawdziwego wybuchu paniki, rzeczywistego rozpadu identyfikacji z reżimem i dyscypliną ${ }^{49}$. Organizacja

46 T.W. Adorno Kierkegaard. Konstruktion des Ästhetischen, J.C.B. Mohr, Tübingen 1933.

47 J. Derrida Goraczka archiwum. Impresja freudowska, przeł. J. Momro, Wydawnictwo IBL PAN, Warszawa 2016, s. 33.

Osobliwość władzy pastoralnej, odróżniającej się od władzy urzędnika czy monarchy, polega na tym, że tam gdzie król widział tylko uległych poddanych, a urzędnik - równych obywateli, władztwo pasterskie próbuje uchwycić „życie każdego". Faszyzm w tym znaczeniu ustanawia władzę mającą "prowadzić każdego" do politycznego zbawienia organicznie zintegrowanego ciała zbiorowego. 
faszyzmu do samego końca pozostała spójna. Oznacza to, że nigdy nie udało się w Niemczech radykalnie zniszczyć identyfikacji z faszyzmem. Wbrew temu, co pisze Foucault, nigdy nie było rozłamu pomiędzy epoką faszyzmu i powojennego liberalizmu ${ }^{50}$. Nowy powojenny cel niemieckiego liberalizmu, zmierzającego nie tyle do wykrojenia rynku wewnątrz społeczeństwa, ile podporządkowania władzy politycznej zasadom gospodarki rynkowej, nie odbywa się za sprawą magicznego cięcia. Twierdzenie, że nie ma innej polityki poza polityką wzrostu gospodarczego, jest raczej wyrazem zapomnienia niż projektowania. Gesellschaftspolitik, która nie anuluje antyspołecznych skutków konkurencji, lecz ma celu samo wytwarzanie społeczeństwa, ponownie stwarza warunki do odrodzenia faszyzmu. Państwo radykalnie ekonomiczne, w którym znak bogactwa odsyła nie tyle do boskiego zbawienia, ile prostej przynależności do narodu, to raz jeszcze symptom - oznaka niezrealizowanego zaspokojenia popędu, to sukces procesu wyparcia.

Tym sposobem wraca Freud, tym razem z tekstem z 1914 roku, zatytułowanym Erinnern, Wiederholen und Durcharbeiten ${ }^{51}$. Sam Adorno wygłasza w 1959 roku wykład wprost nawiązujący do tego tekstu Freuda - "Co to znaczy przepracowywać przeszłość?”.Ten ważny tekst Freuda i nawiązanie do niego przez Adorna przypomina nam, że groźniejsza od zapomnienia jest skłonność do urzeczywistnienia przeszłości w formie działania, a nie zwykłego przypomnienia. Wyparcie przeszłości rodzi dyspozycję do odtwarzania czegoś nie tyle w formie wspomnienia, ile za pomocą czynu właśnie. Czyn to rodzaj powtarzania bez świadomości tego, że się powtarza. Tym właśnie jest powrót faszyzmu, który jest nie widmowy, lecz czysto behawioralny. Przypomina on bardziej przymus ruchowy niż powrót stłumionych treści ideologicznych.

Freud w swoim sztandarowym tekście przypomina o trzech fazach myślenia na temat kategorii „przepracowania”. W pierwszej fazie psychoanaliza próbowała odzyskać stłumione treści przez pracę nad przypominaniem i odreagowaniem za pomocą hipnozy. W fazie drugiej odzyskanie przeszłości dokonywało się przez analizowanie tego, czego przypomnienia sobie analizant odmawiał. Wreszcie w fazie trzeciej praca nad stłumieniem ograniczała się do analizowania oporów. W tej ostatniej fazie mamy do czynienia z nowym podziałem pracy w analizie - analityk koncentruje się tylko na pokonywaniu oporów wyparcia. Pytanie kluczowe dotyczy zatem tego, co karmi opór?

50 M. Foucault Narodziny biopolityki, s. 96-167.

51 S. Freud Przypominanie, powtarzanie, przepracowywanie, przeł. R. Reszke, w: tegoż Technika terapii, Wydawnictwo KR, Warszawa 2007, s. 165-174. 
Najprostsza odpowiedź brzmi: opór jest karmiony poprzez odreagowanie nagromadzonych sum afektów. Wydaje się, że praca analityka zmierza do zatrzymania wszystkich impulsów, które neurotyk chciałby przemieścić w pole motoryczne, odwołując się do motywu drapaka, tj. ucieczki. Interwencja w faszyzm polegałaby więc na tym, aby faszysta nie dał drapaka, nie uciekał od demokracji.

\section{Abstract}

\section{Szymon Wróbel}

UNIVERSITY OFWARSAW

Fascism as a Symptom, Ideological Function and Pattern

Wróbel examines the concept of fascism, which has recently become blurred. Certainly fascism itself has gained new relevance, but do we still know what it is or what it could be? Wróbel distinguishes three ways of understanding fascism - as a symptom, a function or a general ideological pattern - and explores their relationship. He focuses on the relationship between fascism as a "symptom of libidinal conflicts" and "fascism as an ideology," which becomes a pattern for understanding the world. Wróbel also questions the meaning of symptom and ideological pattern before asking of what fascism is symptomatic. Finally he reflects on "fascism in a democracy," i.e. what is fascism if it is not merely political ideology or a symptom, but - following Adorno - a readiness to "accept fascism".

\section{Keywords}

banality, fascism, function, ideological pattern, symptom 